\title{
New morphological and molecular data on the little-known pontellid Calanopia media Gurney, 1927 (Crustacea, Copepoda, Calanoida) from the Red Sea, with notes on its diel vertical distribution
}

\author{
Mohsen M. El-Sherbiny ${ }^{1,2}$, Mamdouh A. Al-Harbi' \\ I Department of Marine Biology, King Abdulaziz University, Jeddah 21589, Saudi Arabia 2 Department of \\ Marine Sciences, Suez Canal University, Ismailia 41522, Egypt
}

Corresponding author: Mohsen M. El-Sherbiny (ooomar@kau.edu.sa)

Academic editor: D. Defaye | Received 1 October 2019 | Accepted 13 February 2020 | Published 25 March 2020

http://zoobank.org/0740222E-7EFC-4D35-B63D-646D94DF2178

Citation: El-Sherbiny MM, Al-Harbi MA (2020) New morphological and molecular data on the little-known pontellid Calanopia media Gurney, 1927 (Crustacea, Copepoda, Calanoida) from the Red Sea, with notes on its diel vertical distribution. ZooKeys 922: 13-33. https://doi.org/10.3897/zookeys.922.46977

\begin{abstract}
As a part of the routine neritic zooplankton collection program in Obhur Creek (central Red Sea, Saudi Arabia), specimens of a pontellid calanoid copepod, Calanopia media Gurney, 1927, were observed and studied. Since the original description was rather brief and drawings limited, especially of mouthparts and legs, which were not illustrated and described, the species is here fully redescribed. Red Sea specimens showed considerable variation in the female genital compound somite, the right caudal ramus and leg 5 , as well as in the presence of a medial knob ventrally on the male right prosomal corner. DNA sequences of mtCOI of different specimens did not show any significant differences and supported their identity as one species. Calanopia media exhibited clear diel vertical migration, with high densities of 106 and 150 ind. $\mathrm{m}^{-3}$ during sunset $(6: 00 \mathrm{pm}$; UTC+3) and midnight (12:00 am; UTC+3) collections, respectively. However, this species was not observed in other zooplankton collections from the surface to $20 \mathrm{~m}$ depth, at 6:00 am and 12:00 pm (UTC+3).
\end{abstract}

\section{Keywords}

Calanopia media, copepods, pontellid, redescription, Red Sea

Copyright M. M. El-Sherbiny, M.A.Al-Harbi. This is an open access article distributed under the terms of the Creative Commons Attribution License (CC BY 4.0), which permits unrestricted use, distribution, and reproduction in any medium, provided the original author and source are credited. 


\section{Introduction}

The pontellid (Calanoida) fauna of the Red Sea contains a surprisingly low proportion of the Indo-Pacific fauna, from which it is apparently derived (El-Sherbiny and Ueda 2008; El-Sherbiny 2009). Five genera and 17 pontellid species have been recorded from the Red Sea (Al-Aidaroos et al. 2019; El-Sherbiny and Al-Aidaroos 2017; Razouls et al. 2019), whereas 77 pontellid species are present in the greater Indian Ocean (Razouls et al. 2019). Among the Red Sea pontellids, there are six species of Calanopia (AlAidaroos et al. 2016; El-Sherbiny and Al-Aidaroos 2017), namely: C. elliptica Dana, 1849, C. minor A. Scott, 1902, C. media Gurney, 1927, C. kideysi Ünal \& Shmeleva, 2002, C. thompsoni A. Scott, 1909 and C. tulina El-Sherbiny \& Al-Aidaroos, 2017. The original description of $C$. media is rather brief, does not include the cephalic and thoracic limbs, and illustrations are confined to habitus drawings of the female and male in dorsal view, the female urosome, the male right antennule ancestral segments 19 and 20 and the male and female leg 5.

During the examination of plankton, samples collected from the Saudi Arabian waters of the central Red Sea, in Obhur Creek, Jeddah, specimens of what we provisionally called $C$. media were observed. These specimens differ in some respects from Gurney's (1927) original description. Here, we provide a full description of the species and an account of variability among the Obhur Creek specimens. Comparison with the type specimens held in the Natural History Museum, London (BMNH 1926.2.16.69-88) was carried out, and information on the vertical migration in the water column was provided. In addition, the mitochondrial COI gene of some species from the Red Sea was sequenced and compared with the sequences available in GenBank (NCBI) to determine their affinity.

\section{Material and methods}

Zooplankton samples were collected from Obhur Creek $\left(21^{\circ} 42^{\prime} 32.23^{\prime \prime N}\right.$, $\left.39^{\circ} 5^{\prime} 41.56^{\prime \prime E}\right)$ using a $50 \mathrm{~cm}$ diameter plankton net of $150 \mu \mathrm{m}$ mesh size, towed near the surface for 10 minutes at a speed of about 1-1.5 knots and vertically from $20 \mathrm{~m}$ depth to the surface on 21 January 2016 at 7:00am, 12:00pm, 6:00pm and 12:00am (UTC+3) local time (sunrise at 7:04am and sunset at 6:05pm; UTC+3). A flowmeter (Hydrobios) was attached to the net mouth for estimating the volume of water filtered. Samples were fixed immediately in 95\% alcohol. Subsequently, Calanopia media specimens were picked from zooplankton samples collected at midnight. For microscopic examination, specimens were dissected in lactic acid and were observed using brightfield and differential interference microscopy (Nikon DM 6000). Drawings and measurements were made with a camera lucida attached to the microscope and an ocular micrometer. Morphological terminology follows Huys and Boxshall (1991), except for maxillary and maxillipedal appendages, which follow Ferrari and Ivanenko (2008). For scanning electron microscopy, Calanopia specimens were washed three times in filtered seawater and clean distilled water, then dehydrated through a 30-100\% ethanol series 
and dried with hexamethyldisilazane. The specimens were mounted on a stub, coated with gold palladium, and observed with a SEM FEI-QUANTA 250.

For genetic analysis, four intact female specimens of $C$. media, three of $C$. minor, one of $C$. elliptica and two of $C$. thompsoni (after accurate morphological identification) were sorted out and the genomic DNA was extracted from individual specimens. A portion of the mitochondrial gene cytochrome oxidase subunit I (mtCOI) was amplified using the universal primers of Folmer et al. (1994). Individual copepods were digested in $400 \mu \mathrm{l}$ ATL buffer (Qiagen) and $20 \mu \mathrm{l}$ Proteinase K overnight, in a capped $0.2 \mathrm{ml}$ microcentrifuge tube. After digestion, $400 \mu \mathrm{l}$ of AL buffer was added and DNA extraction continued using Qiagen's Blood and Tissue kit as per the manufacturer's instructions. DNA was precipitated in $30 \mu \mathrm{l} \mathrm{AE}$ buffer and mtCOI amplicons were amplified using the PCR primers LCO1490 and HCO2198 (Folmer et al. 1994). The reaction conditions were initial denaturation for $5 \mathrm{~min}$ at $95{ }^{\circ} \mathrm{C}$ followed by 40 cycles of $94{ }^{\circ} \mathrm{C}(1 \mathrm{~min}) ; 47^{\circ} \mathrm{C}(2 \mathrm{~min}) ; 72{ }^{\circ} \mathrm{C}(3 \mathrm{~min})$. A final extension at $72{ }^{\circ} \mathrm{C}$ for $10 \mathrm{~min}$ was undertaken. PCR products were purified using ExoStar (Illustra) and sequencing was carried out in an ABI $3730 \times 1$ Capillary Sequencer. The machine-read sequences were compiled using Sequencing Analysis (Ver. 3.3, ABI prism) and manually checked for accuracy. Available sequences of $C$. thompsoni were obtained from the NCBI database for comparison. Pairwise distance measures and phylogenetic analyses were conducted using the MEGA X software (Kumar et al. 2018). Ambiguous sites were eliminated from the dataset.

\section{Results}

\section{Systematics}

Subclass Copepoda Milne-Edwards, 1840

Order Calanoida Sars, 1903

Family Pontellidae Dana, 1852

Genus Calanopia Dana, 1852

\section{Calanopia media Gurney, 1927}

Figs 1-6

Material examined. 36 females (body length: $1.17-1.32 \mathrm{~mm}$, mean \pm SD: $1.25 \pm 0.051 \mathrm{~mm}$ ) and 25 males (body length: $1.10-1.26 \mathrm{~mm}$, mean $\pm \mathrm{SD}$ : $1.14 \pm 0.048 \mathrm{~mm}$ ); whole specimens in $70 \%$ ethanol were deposited in the Natural History Museum, London [Registration number: NHMUK 2018. 1538-1547]. All specimens were collected at Obhur Creek, central Red Sea $\left(21^{\circ} 42^{\prime} 32.23^{\prime \prime N}, 39^{\circ} 5^{\prime} 41.56^{\prime \prime E}\right)$ on 21 January 2016 by M.M. El-Sherbiny.

DNA-barcode. The mitochondrial gene cytochrome oxidase subunit (mtCOI) sequences were submitted to GenBank (GenBank Accession numbers for C. elliptica: MN796254; C. media: MN445608-MN445611; C. minor: MN796251-MN796253; C. thompsoni: MN796255-MN796256). 


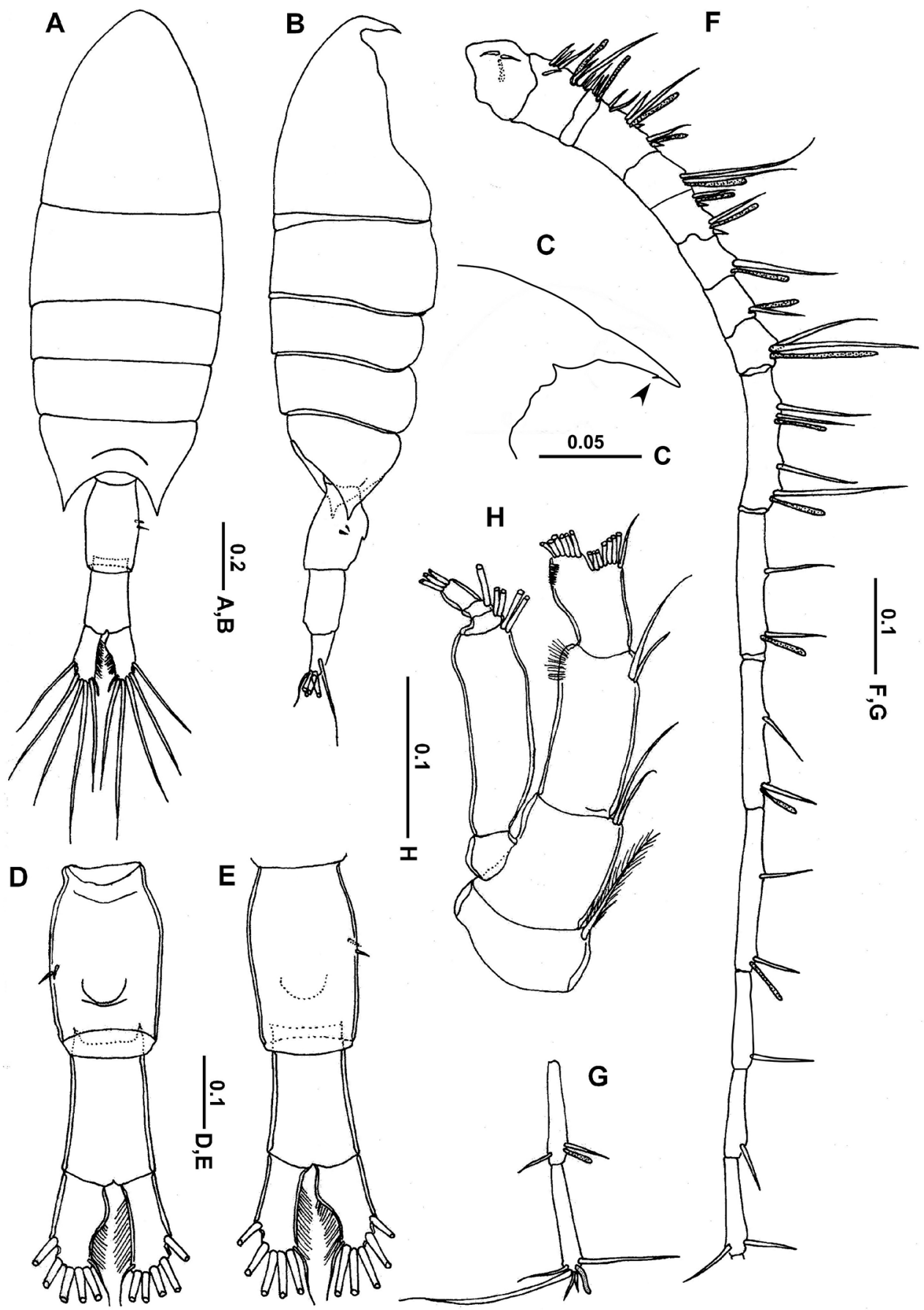

Figure I. Calanopia media female from the Red Sea $\mathbf{A}$ habitus, dorsal view $\mathbf{B}$ habitus, lateral view $\mathbf{C}$ rostrum, lateral view (rudimentary rostral notch indicated by arrow) $\mathbf{D}$ abdomen, ventral view $\mathbf{E}$ abdomen, dorsal view $\mathbf{F}-\mathbf{G}$ antennule $\mathbf{H}$ antenna. Scale bars in $\mathrm{mm}$. 
Description. Female. Prosome (Fig. 1A, B) elliptical, without lateral hooks; cephalosome and first pedigerous somite completely separated; fourth and fifth pedigerous somites completely fused, with dorsal suture visible; posterior corners of prosome symmetrical, sharply pointed, extending nearly one-third of way along genital compound somite. Rostrum with broad base and pair of rounded lobes, each terminating in a tapering point (Figs 1C, 2A). Urosome (Figs 1D, E, 2B, C) with 2 free somites: genital compound somite symmetrical in dorsal view, with 2 unequal ventral spinules on right side, ventral surface with smooth, evenly rounded operculum located posterior to mid-length (Figs 1E, 2C); second urosomite symmetrical and slightly shorter than genital compound somite; caudal rami asymmetrical; right ramus broader and expanded anteromedially, slightly shorter than left ramus, each ramus carrying 5 plumose setae (II-VI) along distal margin and a reduced seta (seta VII) located on dorsal surface near medial distal angle.
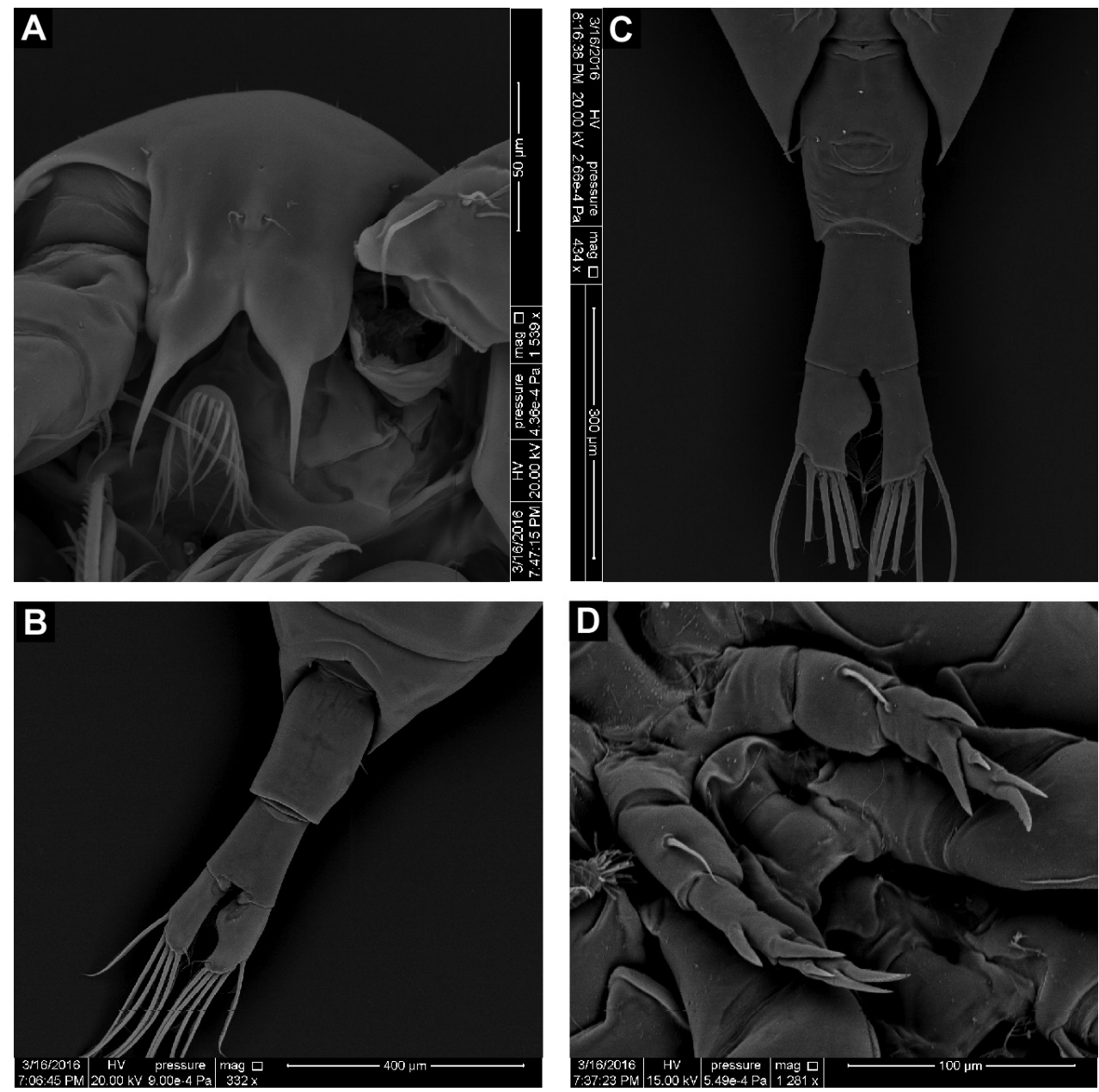

Figure 2. SEM micrographs of Calanopia media female from the Red Sea A rostrum, ventral view B abdomen, dorsal view $\mathbf{C}$ abdomen, ventral view $\mathbf{D}$ leg 5, posterior view. 
Antennules (Fig. 1F, G) 18-segmented, slightly exceeding end of genital compound urosomite. Fusion pattern and armature elements as follows: ancestral segment I (segment 1$)=2$ setae + aesthetasc (ae), II-VI $(2)=8+$ ae, VII $(3)=2+$ ae, VIII-X $(4)=7(2$ spiniform $)+2 \mathrm{ae}, \mathrm{XI}(5)=2+\mathrm{ae}, \mathrm{XII}-\mathrm{XIII}(6)=4(2$ spiniform $)+2 \mathrm{ae}, \mathrm{XIV}$ (7) $=1+\mathrm{ae}, \mathrm{XV}(8)=1+\mathrm{ae}, \mathrm{XVI}(9)=2+\mathrm{ae}, \mathrm{XVII}-\mathrm{XVIII}(10)=4+2 \mathrm{ae}, \mathrm{XIX}(11)=$ $2+\mathrm{ae}, \mathrm{XX}(12)=2+\mathrm{ae}, \mathrm{XXI}(13)=2+\mathrm{ae}, \mathrm{XXII}(14)=1, \mathrm{XXIII}(15)=1, \mathrm{XXIV}(16)$ $=1+1, \operatorname{XXV}(17)=1+$ ae +1, XXVI-XXVIII $(18)=5+$ ae.

Antenna (Fig. 1H) biramous; coxa with plumose seta distomedially; basis carrying 2 subequal plumose setae at distomedial angle; exopod 5 -segmented, second segment longest with setal formula of 0,2, 2, 1, 3. Endopod 2-segmented, first endopodal segment with 2 subequal lateral setae distally and furnished with fine setules distolaterally; second endopodal segment armed with 8 and 6 setae on proximal and distal lobes, respectively, laterodistal border with row of posterior spinules.

Mandible (Fig. 3A). Gnathobase with eight teeth on cutting edge, third and fourth ventralmost teeth bicuspidate; patches of dagger-like spinules arranged at base of third to sixth ventralmost teeth; mandibular palp basis with 4 setae; endopod 2-segmented, first and second segments carrying 3 and 6 setae, respectively; exopod 5-segmented, first to fourth segments each with one seta and fifth segment with 3 setae.

Maxillule (Mx1) (Fig. 3B). Praecoxal endite well developed and extended distally with 9 marginal and 4 posterior setae; coxal exite bearing 9 setae along distal margin; coxal endite with 3 setae; basal exite with long seta, proximal and distal endites with 3 and 2 setae, respectively. Exopod 1-segmented, with a total of 9 terminal setae. Endopod fused to basis, bearing 4 medial and 5 terminal setae.

Maxilla (Mx2) (Fig. 3C). Praecoxal endite of syncoxa with 4 setae; proximal and distal coxal endites bearing 3 setae each; proximal and distal basal endites with 3 and 3 setae, respectively; endopod 3-segmented, with setal formula of 1, 1, 4 .

Maxilliped (Mxp) (Fig. 3D). Praecoxa and coxa completely fused, syncoxa with three endites carrying 2, 3, 2 setae on proximal, middle and distal endites, respectively; basal endite with 2 distal setae; endopod 4-segmented, first endopodal segment long, with 2 setae distally; other three endopodal segments shorter, bearing 1, 1 and 3 setae, respectively.

Legs 1-4 as in other members of the genus, with 3-segmented exopods and 2-segmented endopods as well as lateral spines with serrated hyaline margins (Fig. 4A-D): coxa of legs 1 to 3 bearing one medial seta and a patch of fine setules; coxa of leg 4 without medial seta. Seta and spine formula as follows (spines, Roman numerals; setae, Arabic numerals):

\begin{tabular}{lccccccc}
\hline & Coxa & Basis & \multicolumn{3}{c}{ Exopod } & \multicolumn{2}{c}{ Endopod } \\
\cline { 4 - 8 } & & & $\mathbf{1}$ & $\mathbf{2}$ & $\mathbf{3}$ & $\mathbf{1}$ & $\mathbf{2}$ \\
\hline Leg 1 & $0-1$ & $0-0$ & I-1 & I-1 & II, I, 4 & $0-3$ & $1,2,3$ \\
Leg 2 & $0-1$ & $0-0$ & I-1 & I-1 & III, I, 5 & $0-3$ & $2,2,4$ \\
Leg 3 & $0-1$ & $0-0$ & I-1 & I-1 & III, I, 5 & $0-3$ & $2,2,4$ \\
Leg 4 & $0-0$ & $0-0$ & I-1 & I-1 & III, I, 5 & $0-3$ & $2,2,3$ \\
\hline
\end{tabular}




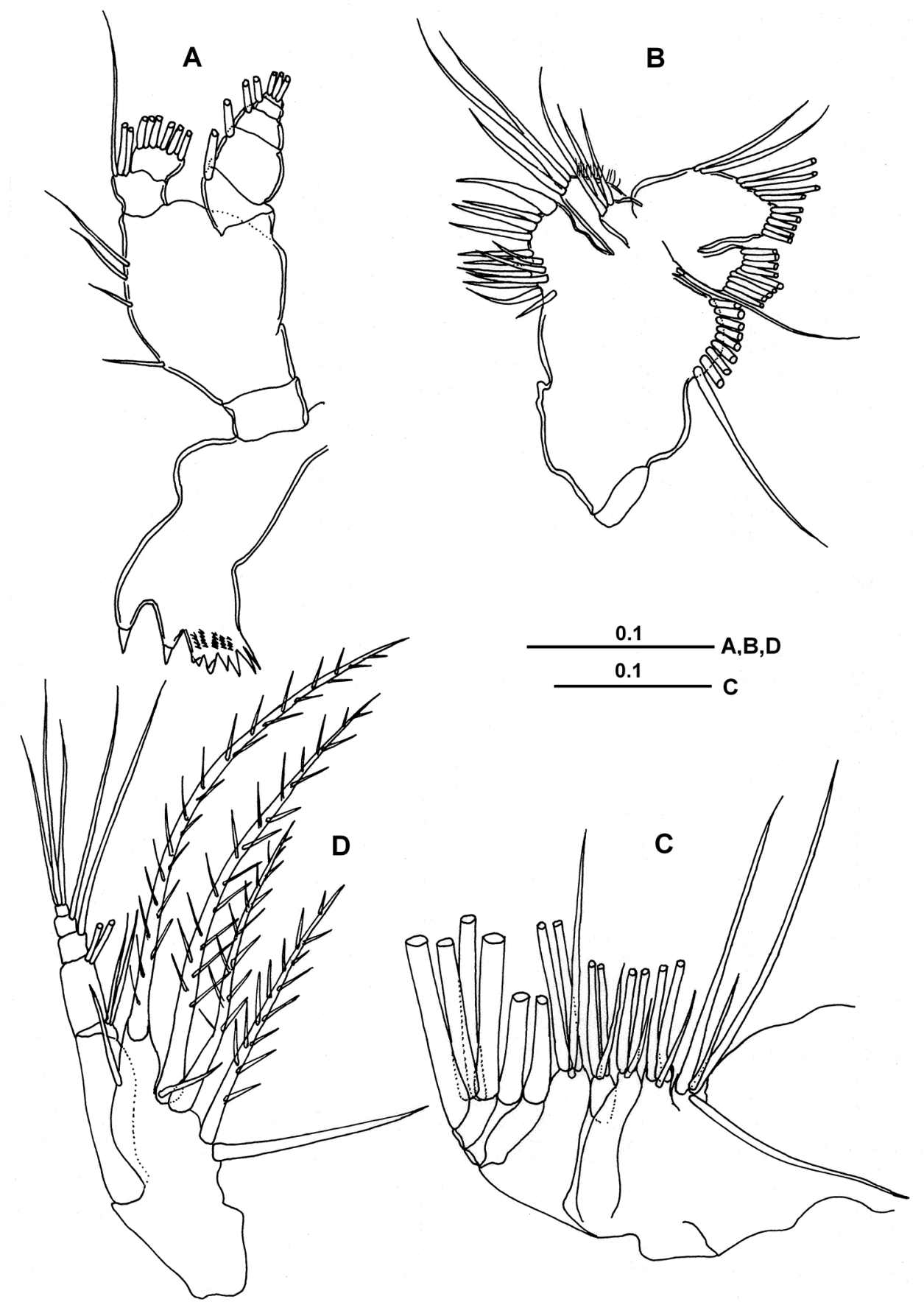

Figure 3. Calanopia media female from the Red Sea $\mathbf{A}$ mandible $\mathbf{B}$ maxillule $\mathbf{C}$ maxilla $\mathbf{D}$ maxilliped. Scale bars in $\mathrm{mm}$. 
A

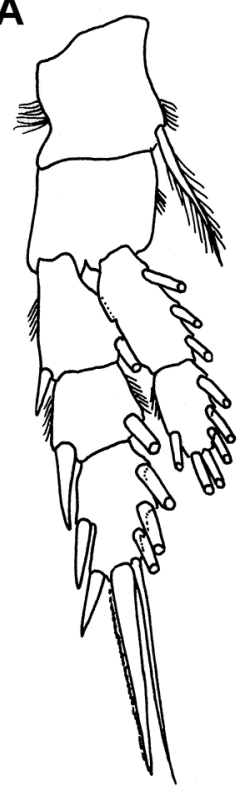

B
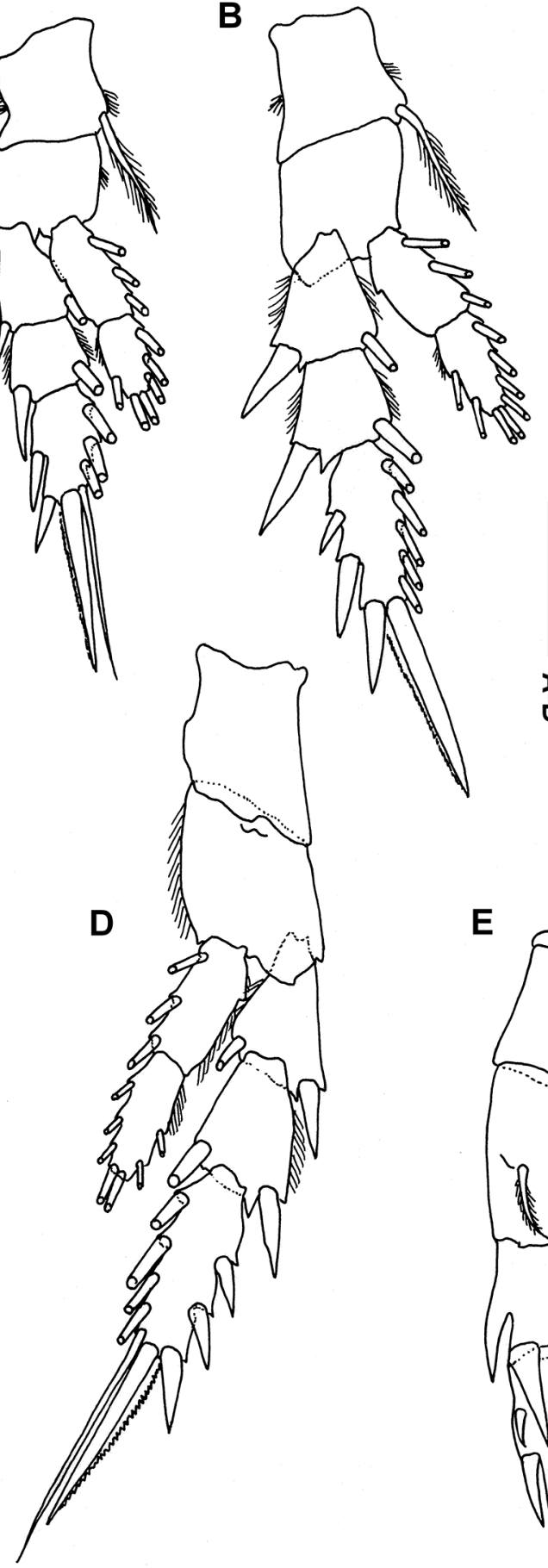

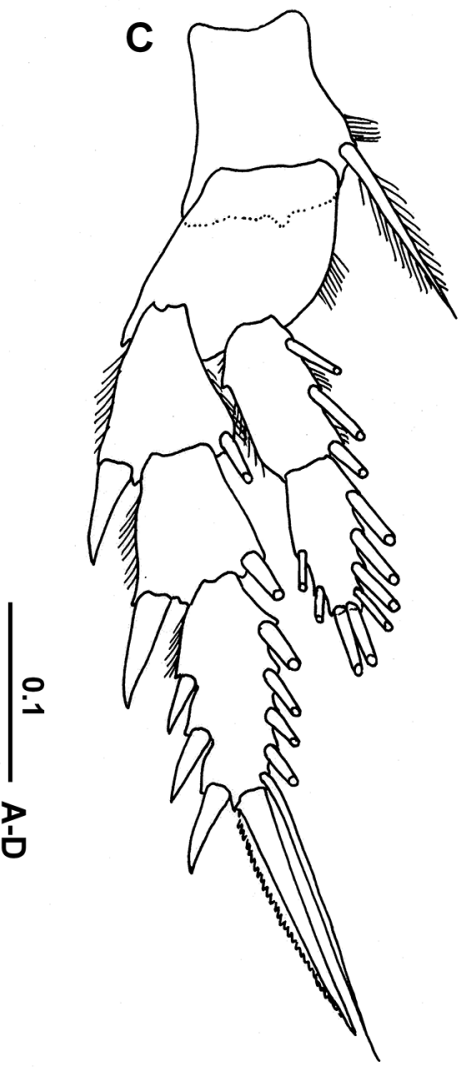

$\mathbf{E}$

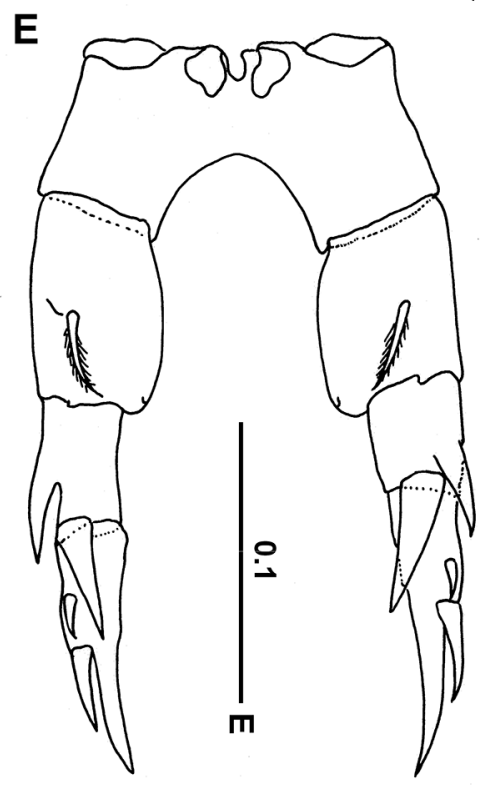

Figure 4. Calanopia media female from the Red Sea $\mathbf{A}$ leg 1, anterior view $\mathbf{B}$ leg 2, anterior view $\mathbf{C}$ leg 3 , anterior view $\mathbf{D}$ leg 4, posterior view $\mathbf{E}$ leg 5, posterior view. Scale bars in $\mathrm{mm}$. 
Leg 5 (Fig. 4E) asymmetrical but with same number of spines and processes; coxa and intercoxal sclerite completely fused; right basis broader and slightly shorter than left basis, each with one posterior plumose seta; exopod 2-segmented; first exopodal segment of right leg shorter than that of left leg; with 1 lateral fused process and 1 strong spine distally; second exopodal segment of right leg slightly longer than that of left leg, extending into tapering process fused to its segment, with 2 lateral articulated spines (proximal one smaller).

Male. Prosome (Fig. 5A) 2.1 times as long as urosome; cephalosome and first pedigerous somite completely separated; fourth and fifth pedigerous somites completely fused (Figs 5A, 6B); rostrum as in female (Fig.5 B, C); posterior corners of prosome slightly asymmetrical (right one slightly longer than left), with a sharp triangular process directed posteriorly and with a distinct ventral knob or process on its right medial margin, which cannot be seen in dorsal view (Figs 5D, 6B). Urosome composed of 5 free somites, genital somite with genital aperture located ventrolaterally on posterior left side margin; second urosomite longer than other somites; anal somite shorter than preceding somite; caudal rami symmetrical, 2.2 times longer than wide, each ramus with 6 setae (II-VI) and seta VII small, inserted in ventrodistal medial margin.

Antennule (Figs 5E, F, 6C) geniculate on right side, left one similar to that of female (except for second segment, which carries longer posterior setae): right one indistinctly 17-segmented, segments 3-4 incompletely fused ventrally, segments 5-6 and 7-8 completely fused dorsally, segment 13 with long denticles on proximal 1/4 and short denticles that extend to distal fourth part, segment 14 tooth ridge possessing triangle denticles proximally, which extend back to distally-directed spure-like process, armature as follows: ancestral segment I (segment 1) = 2 setae + aesthetasc (ae), II-V (2) $=8+2 \mathrm{ae}, \mathrm{VI}(3)=2+\mathrm{ae}$ VII $(4)=2+\mathrm{ae}, \mathrm{VIII}-\mathrm{IX}(5)=4$ (2 spiniform $)+2 \mathrm{ae}, \mathrm{X}-$ $\mathrm{XI}(6)=4(1$ spiniform $)+$ ae, XII $(7)=1+$ ae, XIII $(8)=1+$ ae, XIV (9) $=2+$ ae, XV $(10)$ = naked, XVI-XVII $(11)=3+2$ ae, XVIII-XIX (12) = 1+ process $]+$ ae, XX (13) $=1+\mathrm{ae}, \mathrm{XXI}-\mathrm{XXIII}(14)=2+$ process $+\mathrm{ae}, \mathrm{XXIV}(15)=1+1, \mathrm{XXV}(16)=1+\mathrm{ae}+1$, XXVI-XXVIII $(17)=5+$ ae.

Antenna, mouthparts and legs 1-4 as in female. Leg 5 (Figs 5G, 6D) uniramous, asymmetrical; coxae and intercoxal sclerite completely fused. Left leg basis carrying 1 plumose seta posteriorly near two-thirds of its length; exopod 2-segmented, first segment shorter than basis ( 0.46 times) with small laterodistal spine; second segment nearly 1.35 times as long as first one, bearing 3 articulated spines (2 stout apically and one small laterally), medial hirsute margin with one distal fused spine. Right leg 5 (Figs 5G, 6D), longer than left; basis slightly longer than coxa, carrying one posterior plumose seta; right exopod 2-segmented, first segment with small thumb-like process located at approximately one-third of segment length, with small seta near base of thumb, lateral margin concave with bilobed flap-like process; second exopodal segment approximately 0.7 as long as first exopod segment, curved at about mid-length and bluntly rounded distally, bearing 2 setae in depression (one proximal and one central) and 2 unequal outer setae at mid-length (proximal one longer than distal). 


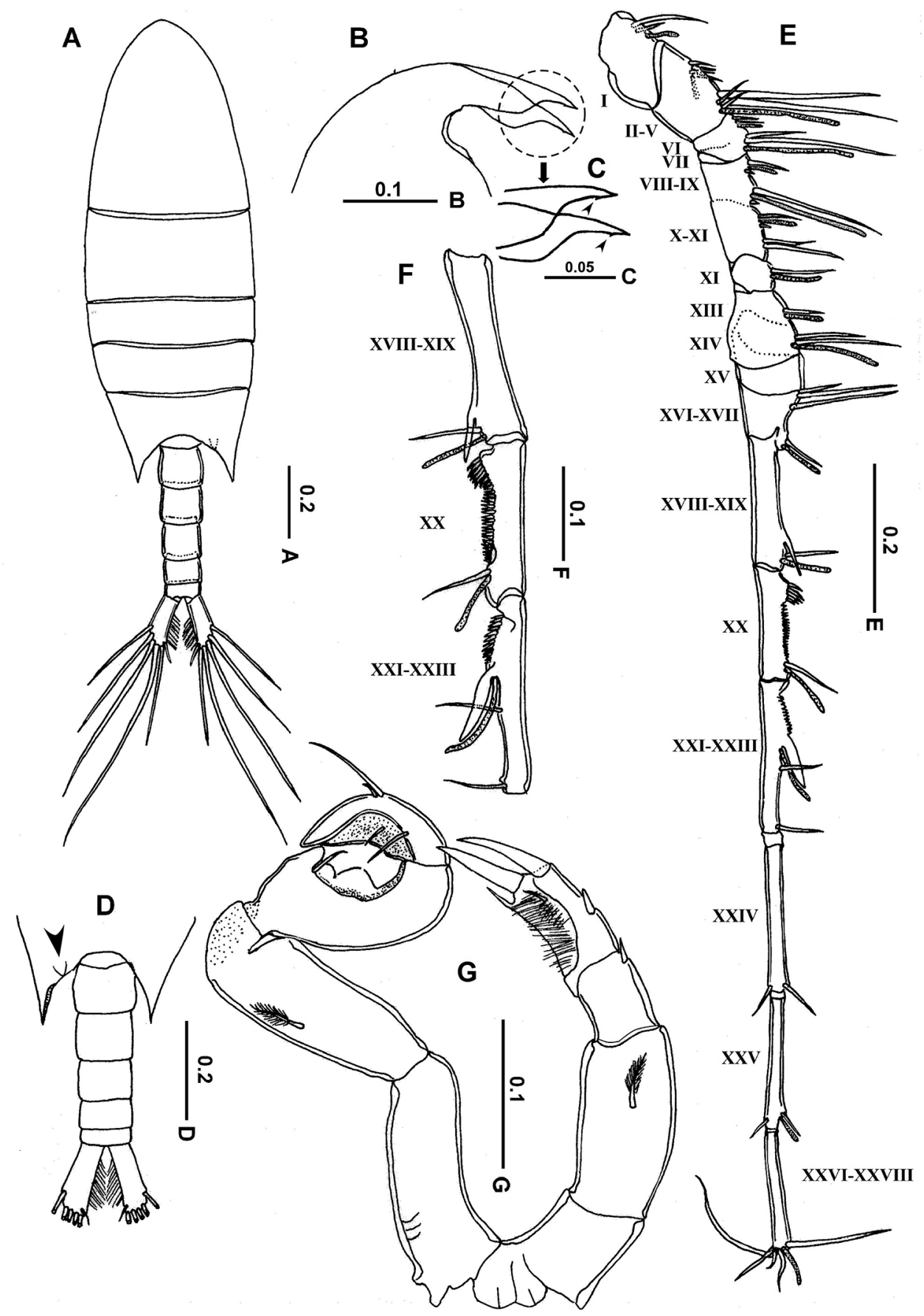

Figure 5. Calanopia media male from the Red Sea $\mathbf{A}$ habitus, dorsal view $\mathbf{B}$ rostrum, lateral view $\mathbf{C}$ enlarged rostral filaments (rudimentary rostral notch indicated by arrow) $\mathbf{D}$ abdomen, ventral view (knob indicated by arrow) $\mathbf{E}$ right antennule $\mathbf{F}$ enlarged segments XVIII-XXIII G leg 5, posterior view. Scale bars in mm. 

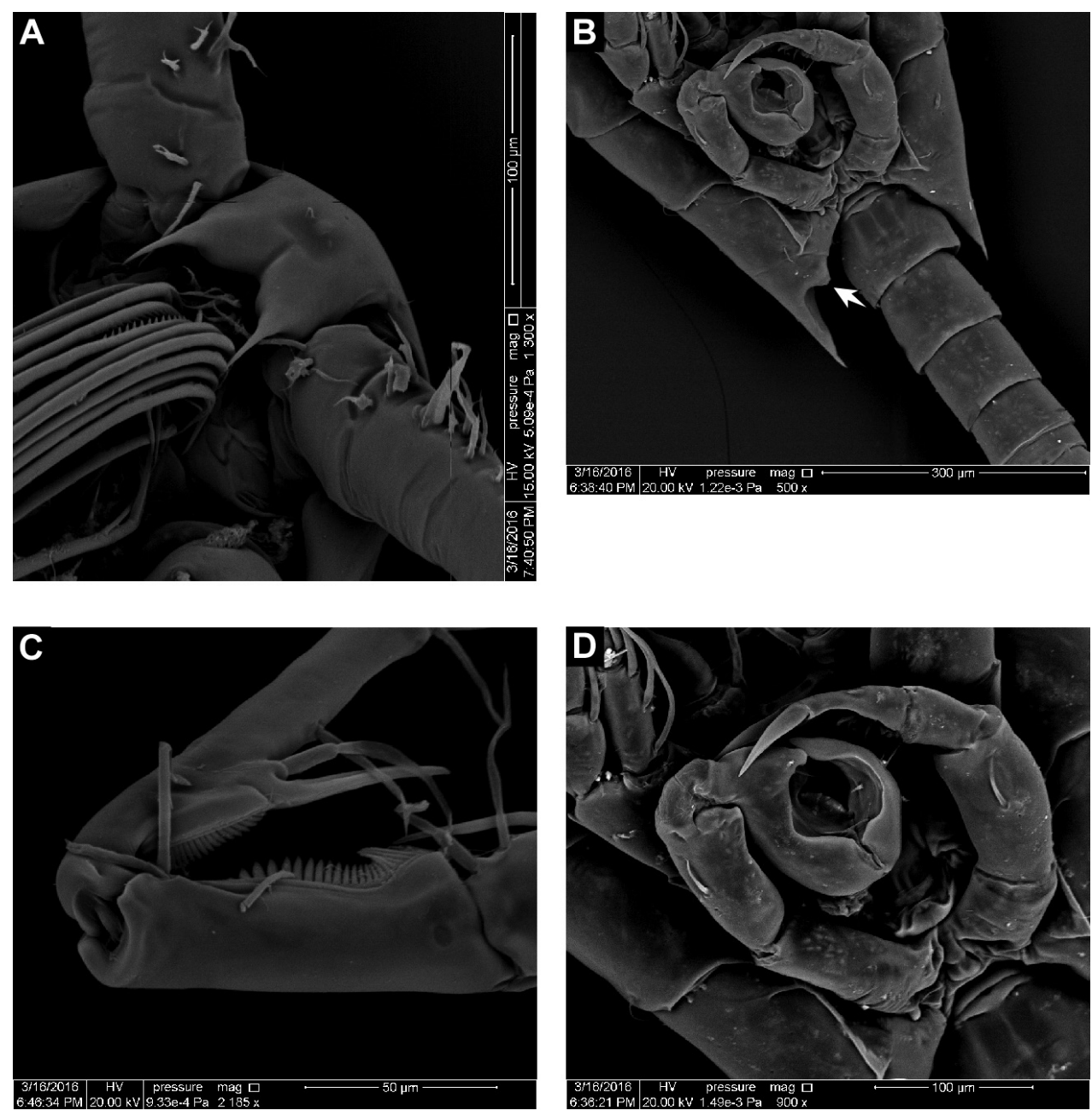

Figure 6. SEM micrograph of Calanopia media male from the Red Sea A rostrum, ventral view B prosomal end with abdomen, ventral view (medial notch indicated by arrow) $\mathbf{C}$ enlarged segments XX-XXIII D male leg 5, posterior view.

Variations. On the ventral surface of the female genital compound somite of some specimens, a small fold in the cuticle may be found on the right or left side. Also, the degree of anteromedial expansion of the female right caudal ramus varies among specimens. The anteromedial expansion of the female right caudal ramus was present in most of the specimens collected from the study area (about $90 \%$ of the population), and sometimes the degree of this expansion varied greatly among specimens. In some specimens, the right caudal ramus had a concave or straight medial margin. Moreover, the ventral knob on the right side of the male prosome posterior corners varies in size. 


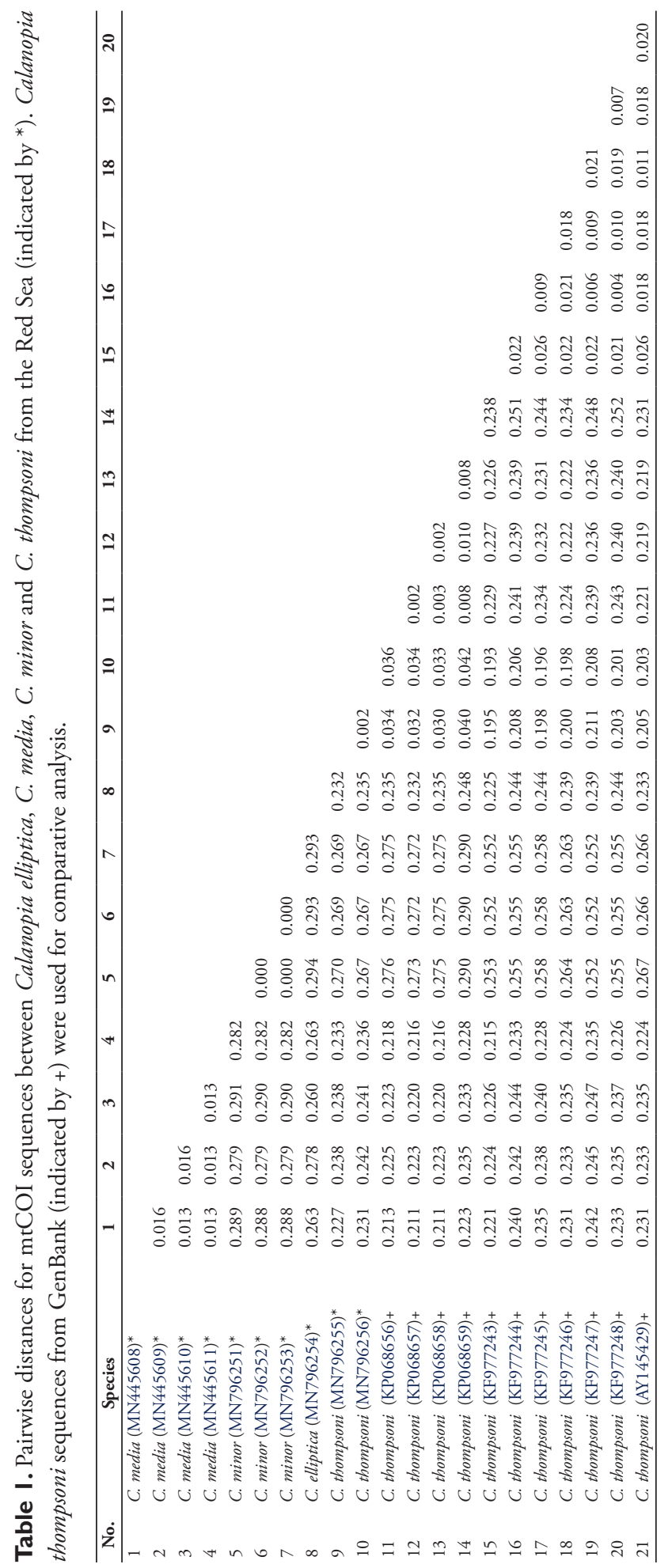


Remarks. We compared our specimens with the paratypes deposited at the Natural History Museum, London (BMNH 1926.2.16.69-88), and concluded that our specimens are $C$. media. Both our specimens and the paratypes shared most of the diagnostic features of the species, such as: the shape of the fifth pediger, the presence of 2 ventral spinules on the right side of the female genital compound somite, and the structure of both female and male leg 5. However, the asymmetry of female leg 5 (right leg basis broader and slightly shorter than left, first exopodal segment of right leg shorter than that of left leg and second exopodal segment of right leg slightly longer than on left leg) and the presence of a ventral knob on the right side of the prosome were probably overlooked in the original description by Gurney (1927). Nevertheless, our specimens differ in the asymmetry of the caudal rami, of which the right ramus is broader and expanded anteromedially, and slightly shorter than the left one.

Distribution. Calanopia media was originally described from the Suez Gulf and the southern part of the Suez Canal (Gurney 1927) during the CAMBRIDGE Expedition. Subsequently, Pesta (1941) collected this species during the POLA Expedition in the southern Red Sea $\left(1^{\circ} 26^{\prime} 12^{\prime \prime} \mathrm{N}, 4^{\circ} 05^{\prime} 24^{\prime \prime} \mathrm{E}\right)$. In 1956, Rose recorded this species from the Vietnamese waters. Later, it was recorded from the Levantine Basin by Berdugo (1968) and Lakkis (1984) and considered to be a Lessepsian migrant species. In the present study, $C$. media was found in considerable abundance (106 ind $\left.\mathrm{m}^{-3}\right)$ in samples collected at sunset $(6: 00 \mathrm{pm}$; UTC+3), with the highest densities at midnight (150 ind. $\mathrm{m}^{-3}$ ). Copepodid stages were relatively low, constituting 9 and $5 \%$ of the population at sunset and midnight, respectively. It was completely absent from near the surface in morning and midday samples. The sex ratio (males/females) of $C$. media varied between 0.46 and 0.54 at 6:00 pm and 12:00 am (UTC+3), respectively.

Molecular diversity. A 624-bp region of the mtCOI was obtained for four female individuals of $C$. media, which varied in the degree of anteromedial expansion of the female right caudal ramus in specimens collected from Obhur Creek, central Red Sea. Results showed that the four analyzed specimens have nearly identical mtCOI sequences, with a distance ranging between 0.013 and 0.016 based on the pairwise distance method and Kimura 2 parameter model. The intraspecific variation in the mtCOI sequences of the other Red Sea species, $C$. minor and C. thompsoni, were 0.000 and 0.002 , respectively.

Moreover, in the current analysis, sequences were obtained for three other Calanopia species collected from the study area (C. elliptica, C. minor and C. thompsoni) and sequences of one species ( $C$. thompsoni) were obtained from NCBI. The mtCOI sequences of Calanopia species (i.e., C. elliptica, C. media, C. minor and C. thompsoni) from the Red Sea differ between 21.3\% and 29.4\% (Table 1 and Fig. 7). A Neighbor Joining phylogenetic analysis using the Kimura 2 parameter model showed that $C$. media was clearly distinct from its congeneric species (Fig. 7). Concerning C. thompsoni, the only sequenced $\mathrm{mtCOI}$ in $\mathrm{NCBI}$, it is clear that the average distance between Red Sea specimens and Indian Ocean specimens (KP068656-KP068659) was 0.035 (0.030-0.042), whereas for the China seas' specimens it was $0.201(0.193-0.211)$. 


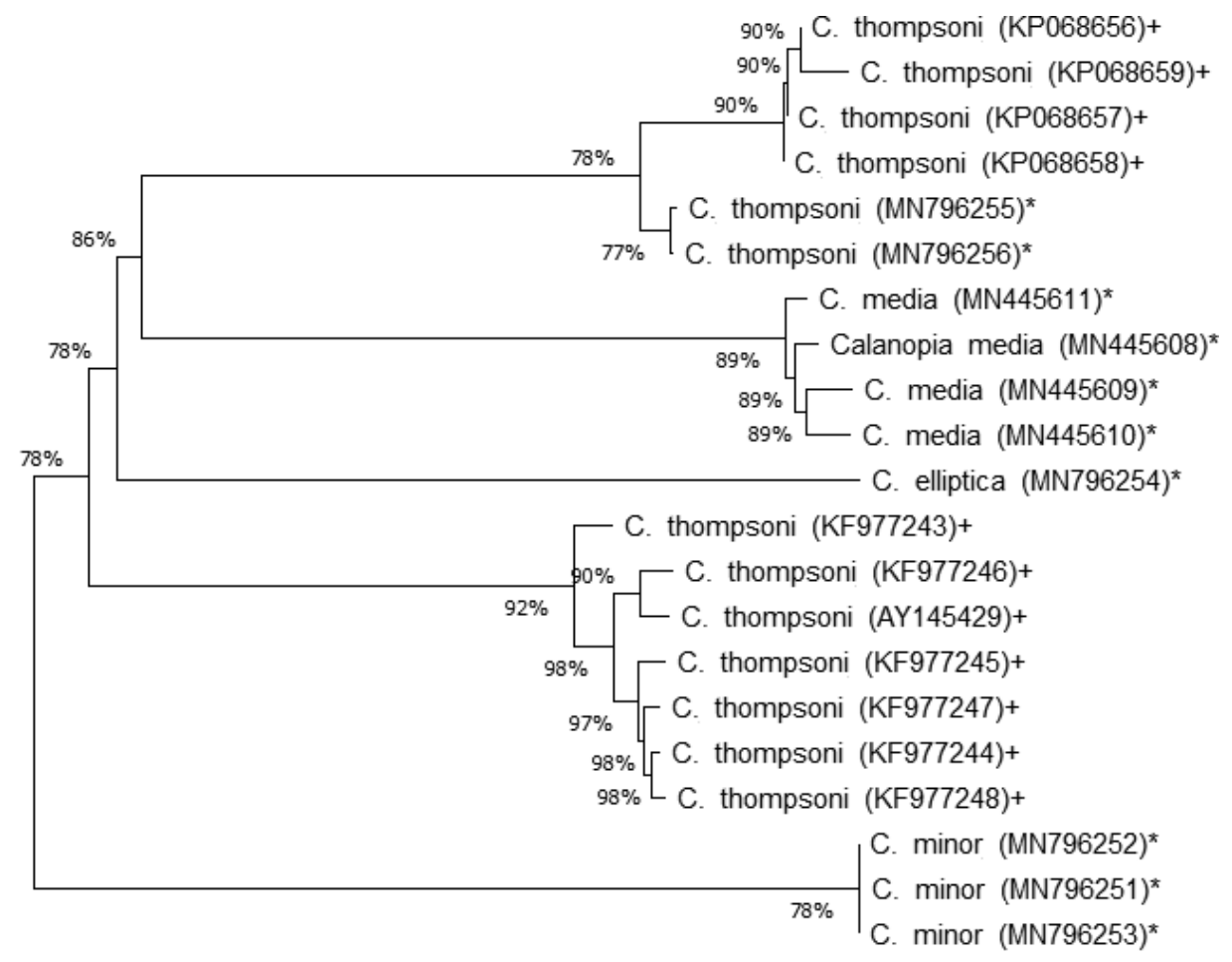

0.020

Figure 7. Neighbor Joining phylogenetic tree based on the mtCOI genes of Calanopia elliptica, C. media, C. minor and C. thompsoni from the Red Sea (indicated by *). Calanopia thompsoni sequences (indicated by +) from GenBank were used for comparative analysis.

\section{Discussion}

In his original description of C. media, Gurney (1927) provided drawings only for the whole body and leg 5 of both sexes, as well as of the female urosome and the geniculate part of the male right antennule (segments XX and XXI), and compared it with $C$. elliptica. His description was brief and focused mainly on the female genital compound somite and female leg 5. For the male, he only mentioned that the major differences between $C$. media and C. elliptica lay in a lack of serrations on the second exopodal segment of right leg 5 . In his words, "Fifth legs closely resembling those of C. elliptica, but without the scalloped edge to the broad subterminal joint of the right leg". Re-examination of $C$. media from the study area allowed us to more accurately describe this species. The original characters reported by Gurney (1927) are given in brackets: 1) the female genital compound carries one or two spinules on the right side (2 spinules); 2 ) the female caudal rami are asymmetrical, the right one is expanding anteromedially (symmetrical); 3) the female leg 5 is slightly asymmetrical, with 
the left leg slightly shorter than the right due to shortness of both the basis and first exopodal segment (mentioned as symmetrical by Gurney, but from his drawings the first exopodal segment is longer on the right side and also the right second exopod segment is longer than the left one); 4) the male prosomal corners project posterolaterally into asymmetrical pointed processes, the right one of which is slightly longer than the left, with a distinct ventral knob on its medial margin, invisible in dorsal view (symmetrical); and 5) the second exopod segment of the male right leg 5 carries one seta medially, which is lacking in Gurney's description. Moreover, Pesta (1941), in his description from the southern Red Sea, mentioned the lack of spinules on the genital compound somite, while the female leg 5 exopod proportions differed slightly from Gurney's description (in Pesta's description, the second exopod segment is 1.1 times as long as the first exopod segment) and the second distal spine on the second exopod segment is shorter than in Gurney's description.

In addition to the variability noted in the caudal rami of $C$. media, variation has been reported in C. sewelli Jones \& Park, 1967, collected from Marquesas, central Pacific, in which the right ramus was sometimes longer and with a concave medial margin. Moreover, asymmetry of the female caudal rami has been noted in C. asymmetrica Mulyadi \& Ueda, 1996 collected from Indonesian waters, where the right ramus was much longer than the left one and expanded posteriorly. This asymmetry was found also in C. australica Bayly \& Greenwood, 1966 collected from Moreton Bay, Australia, in which the left ramus was longer than the right. Asymmetry of the male prosomal points in C. media is similar to that in C. sarsi C.B. Wilson, 1950 collected from Fiji waters and C. tulina (El-Sherbiny and Al-Aidaroos 2017) described from the Red Sea.

Calanopia media is closely related to C. tulina from the central Red Sea, but they can be distinguished from each other by the characters listed in Table 2. The most distinctive characters of $C$. media are: 1) the presence of 2 ventral spinules on the right side of the female genital compound somite, 2) the extreme asymmetry of the caudal rami of the female, 3 ) the presence of 2 long articulated and 1 short fused terminal spines on the second exopodal segment of the male left leg 5,4) the first exopodal segment of male right leg 5 with a small thumb located approximately at one-third of the segment length and with the semicircular processes on a flap on its lateral part, and 5) the second exopodal segment of the male right leg 5 shorter than the first exopodal segment, which is curved at mid-length with a blunt apex and 2 medial setae within a shallow medial depression.

In our study, C. media exhibited a clear diel vertical migration (DVM). Sunset ascend and sunrise descent were performed at very low light intensities. This pattern is known as the nocturnal or normal DVM (Forward 1988). Similar observations were made in previous studies in the southern part of the Suez Canal and the southern Red Sea by Gurney (1927) and Pesta (1941), respectively, who reported that $C$. media was found in high abundance in the coastal waters mainly in the night samples. This pattern was recorded also for C. americana F. Dahl, 1894 in the eastern Gulf of Mexico (Turner et al. 1979) and in the Brazilian waters (Pessoa et al. 2014). This DVM may 
Table 2. Comparative list of characters of Calanopia media and C. tulina. The characters of C. tulina are taken from the original description by El-Sherbiny and Al-Aidaroos (2017).

\begin{tabular}{|c|c|c|}
\hline & Calanopia media & Calanopia tulina \\
\hline \multicolumn{3}{|l|}{ Female } \\
\hline Rostral points & With rudimentary subterminal notch & With small subterminal notch \\
\hline $\begin{array}{l}\text { Genital compound } \\
\text { somite }\end{array}$ & With two spinules on right side & Without any spinules \\
\hline Caudal rami & $\begin{array}{l}\text { Asymmetrical, right one slightly shorter than left and } \\
\text { expanded antero-medially (varies between individuals) }\end{array}$ & Asymmetrical, right one slightly shorter than left \\
\hline Leg 5 & $\begin{array}{c}\text { Asymmetrical; right basis boarder and shorter than right; } \\
\text { right first and second exopodal segments shorter than } \\
\text { on left }\end{array}$ & $\begin{array}{l}\text { Asymmetrical; left leg slightly shorter than right; left basis, } \\
\text { first and second exopodal segment shorter than on right }\end{array}$ \\
\hline \multicolumn{3}{|l|}{ Male } \\
\hline Rostral points & With rudimentary subterminal notch & With small subterminal notch \\
\hline Posterior prosome & $\begin{array}{l}\text { Asymmetrical, right point slightly longer, with small } \\
\text { ventral knob on medial margin }\end{array}$ & $\begin{array}{l}\text { Asymmetrical, right point wider and slightly longer, with } \\
\text { distinct knob on medial margin }\end{array}$ \\
\hline $\begin{array}{l}\text { Second exopodal } \\
\text { segment of left leg } 5\end{array}$ & $\begin{array}{l}\text { With } 3 \text { articulated spines ( } 2 \text { stout and terminal, and one } \\
\text { small and lateral) }\end{array}$ & $\begin{array}{l}\text { With } 2 \text { relatively long curved, terminal medially-serrated } \\
\text { articulated spines and } 1 \text { lateral spine directed medially }\end{array}$ \\
\hline $\begin{array}{l}\text { First exopodal } \\
\text { segment of right leg } 5\end{array}$ & $\begin{array}{l}\text { With small thumb-like process located at one-third of } \\
\text { segment length, with bilobed flap-like process }\end{array}$ & $\begin{array}{l}\text { With very small rounded-tip thumb-like process located } \\
\text { nearly mid-length, central medial part smooth, not bilobed }\end{array}$ \\
\hline $\begin{array}{l}\text { Second exopodal } \\
\text { segment of right leg } 5\end{array}$ & $\begin{array}{l}\text { Curved at mid-length with } 2 \text { setae on concave surface, and } \\
\text { with } 2 \text { unequal setae at mid-length on convex surface }\end{array}$ & $\begin{array}{l}\text { Curved at two-thirds length, with } 2 \text { setae on concave } \\
\text { surface, and } 2 \text { unequal setae at mid-length on convex } \\
\text { surface. }\end{array}$ \\
\hline
\end{tabular}

be performed to avoid UV radiation, light and predators, as well as for availability of food and favorable temperature (Bollens and Frost 1989; Lampert 1989; Andersen and Nival 1991; Pearre 2003; Cohen and Forward 2005). Generally, the light intensity in Obhur Creek drops steeply below $5 \mathrm{~m}$ depth, and very little light penetrates into waters below $15 \mathrm{~m}$ (Al-Aidaroos et al., unpublished data). Following the same trend, UVB radiation decreased by $74.15 \%$ at $5 \mathrm{~m}$ depth, while only $2 \%$ reached $15 \mathrm{~m}$ depth (Duarte et al., unpublished data). This suggests that C. media is avoiding high temperature, high light intensity and/or visual predation during the day and coming up to the surface layers for feeding during night-time. This species was observed to be abundant in night collections by light trap from a shallow coral reef in the central Red Sea (unpublished data). This might be attributed to its benthopelagic behavior, which is clearly visible in terms of the stout, large outer spines on its legs (1-4), as reported in the benthopelagic copepod genus Platycopia (Ohtsuka et al. 1998).

Morphology can be considered as a fundamental method for copepod species identification. However, some pontellid species display considerable intraspecific morphological variations in the female genital compound somite, caudal rami and fifth leg (Jeong et al. 2014). Such differences might be sufficient to prove the presence of a new species, as it is the case for some centropagoid species (e.g. Sakaguchi and Ueda 2010; Soh et al. 2012). The mtCOI gene was proposed as a unique tool for copepod identification with 'barcoding' (Bradford et al. 2010; Blanco-Bercial et al. 2014), which can verify the species identity within morphologically varying pontellid specimens. Within Crustacea, the level of genetic variation between congeneric species is $17.16 \%$, while the level of intraspecific variability is $0.46 \%$ (Costa et al. 2007). Moreover, variation between calanoid copepod species varied between $13-22 \%, 17.6-26.7 \%$ and $21-23 \%$ in previous studies by Bucklin et al. (1999), Eyun et al. (2007) and Soh et al. (2013), respectively. In this 
study, the intraspecific variation in the COI sequences from the Red Sea specimens of $C$. media, C. minor and C. thompsoni would confirm the hypothesis of Costa et al. (2007). The Calanopia species nucleotide sequences collected from GenBank indicate no genetic differentiation between the specimens of $C$. thompsoni from the Red Sea and the Indian Ocean. In contrast, the nucleotide data of $C$. thompsoni from the Red Sea revealed considerable variations with specimens collected from the China seas, indicating that the two populations are genetically different. This high level of deviation between both populations can by supported by the allopatric speciation hypothesis of Carpenter and Springer (2005), which states that in the Pleistocene the migration of marine organisms from the West Pacific Ocean to the Indian Ocean seems to be blocked by an ecological vicariant. Moreover, sequences included herein from the Red Sea are the first barcodes for these species, and it will be useful in future pontellid barcode studies.

During the last two decades, six species of pontellids have been originally described as new species or were first recorded from the Red Sea: Calanopia kideysi by Ünal and Shmeleva (2002), Labidocera boxshalli El-Sherbiny \& Ueda, 2010 by ElSherbiny and Ueda (2010), Calanopia tulina by El-Sherbiny and Al-Aidaroos (2017), Pontella princeps Dana, 1849 by El-Sherbiny (2009), Labidocera karachiensis FazalUr-Rehman, 1973 by El-Sherbiny and Ueda (2008), and Calanopia thompsoni by AlAidaroos et al. (2016). However, the diversity of this family in the Red Sea is rather low (17 species) compared with that of the Indian Ocean (77 species as reported by Razouls et al. 2019), from which the Red Sea fauna has originated (Al-Aidaroos et al. 2019). This low number can be attributed to the characteristic euneustonic or facultative neustonic nature of this group (Mauchline 1998). Thus, inappropriate sampling methods and sampling time and/or limited sampling effort might have resulted in an underestimation of the fauna of Pontellidae. Therefore, this study emphasizes the necessity of understanding the diversity and distribution of pontellid copepods in the Red Sea and their mode of life.

\section{Key to species of Calanopia recorded in the Red Sea}

\section{Females}

$1 \quad$ Leg 5 exopod one-segmented

- Leg 5 exopod two-segmented ............................................................ 3

2 Genital compound somite shorter than second urosomite; exopodal segment of leg 5 with two small lateral spines and one long medial spine (longer than the segment itself).

C. minor

- Genital compound somite nearly equal to second urosomite; exopodal segment of leg 5 with two small lateral spines and one medial spine (shorter than the segment itself) C. kideysi

3 Cephalic lateral hooks absent 4

- Cephalic lateral hooks present 
4 Genital compound somite naked, without lateral spinules 5

- Genital compound somite with two lateral spinules on the right side....C. media

5 Leg 5 asymmetrical; left leg distinctly longer than right one. C. elliptica

- Left leg 5 slightly asymmetrical; right leg slightly shorter than left one.... C. tulina

\section{Males (C. kideysi not included since the adult male is unknown)}

1 Cephalic lateral hooks absent 2

- Cephalic lateral hooks present C. thompsoni

2 Left leg 5 shorter than right one; basis of left leg 5 not swollen proximally........3

- Left leg 5 longer than right one; basis of left leg 5 swollen proximally and produced into a small curved tooth ............................................................ C. minor

3 Second urosomite with one acuminate-tip spinose process postero-laterally on right side; first exopodal segment of right leg 5 with three strong blunt teeth and second exopodal segment claw-like with three small pointed teeth .... C. elliptica

- Second urosomite naked; first and second exopodal segments of right leg 5 without any teeth

4 Second exopodal segment of left leg 5 with three articulated spines (two stout terminally, one small laterally); second exopodal segment of right leg 5 curved at mid-length with a relatively short spine laterally.

C. media

- Second exopodal segment of left leg 5 with two relatively long curved, terminal, medially-serrated spines and one lateral spine directed medially; second exopodal segment of right leg 5 curved at two-thirds of length, with relatively long spine laterally

C. tulina

\section{Acknowledgments}

This project was funded by the Deanship of Scientific Research (DSR), King Abdulaziz University, Jeddah, under grant No. (DF-400-150-1441). The authors, therefore, gratefully acknowledge DSR technical and financial support. The authors also thank Prof. Janet Bradford-Grieve for her critical comments on an earlier draft. Thanks to Miranda Lowe, the curator of crustaceans, Natural History Museum, London, UK, for loaning us the paratype material. Many thanks also to Dr. Stamatina Isari for assistance and help with sequencing and to Dr. Benjamin Kurten for the translation of Pesta’s paper.

\section{References}

Al-Aidaroos AM, El-Sherbiny MM, Mantha G (2019) Copepoda-Their status and ecology in the Red Sea. In: Najeeb R, Stewart ICF (Ed.) The Red Sea: The Formation, Morphology, Oceanography and Environment of a Young Ocean Basin. Springer, 453-475. https://doi. org/10.1007/978-3-319-99417-8_25 
Al-Aidaroos AM, Salama AJ, El-Sherbiny MM (2016) New record and redescription of Calanopia thompsoni A. Scott, 1909 (Copepoda, Calanoida, Pontellidae) from the Red Sea, with notes on the taxonomic status of $C$. parathompsoni Gaudy, 1969 and a key to species. Zookeys 552: 17-32. https://doi.org/10.3897/zookeys.552.6180

Andersen V, Nival P (1991) A model of the diel vertical migration of zooplankton based on euphausiids. Journal of Plankton Research 49: 153-175. https://doi. org/10.1357/002224091784968594

Berdugo V (1968) Sur la présence dans la Méditerranée orientale de deux espèces du genre Calanopia (Copepoda, Calanoida). Rapports et Procès-Verbaux des Réunions, Commission Internationale pour I'Exploration Scientifique de la mer Méditerranée 19(3): 445-446.

Blanco-Bercial L, Cornils A, Copley N, Bucklin A (2014) DNA barcoding of marine copepods: assessment of analytical approaches to species identification. PLoS Currents 6: 1-31. https://doi.org/10.1371/currents.tol.cdf8b74881f87e3b01d56b43791626d2

Bollens SM, Frost BW (1989) Zooplanktivorous fish and variable diel vertical migration in the marine planktonic copepod Calanus pacificus. Limnology and Oceanography 34: 10731083. https://doi.org/10.4319/lo.1989.34.6.1072

Bradford T, Adams M, Humphreys F, Austin AD, Cooper SJB (2010) DNA barcoding of stygofauna uncovers cryptic amphipod diversity in a calcrete aquifer in Western Australia’s arid zone. Molecular Ecology Resources 10: 41-50. https://doi.org/10.1111/j.17550998.2009.02706.x

Bucklin A, Guarnieri M, Hill RS, Bentley AM, Kaartvedt S (1999) Taxonomic and systematic assessment of planktonic copepods using mitochondrial COI sequence variation and competitive, species-specific PCR. Hydrobiologia 401: 239-254. https://doi. org/10.1023/A:1003790411424

Carpenter KE, Springer VG (2005) The center of the center of marine shore fish biodiversity: the Philippine Islands. Environmental Biology of Fishes 72: 467-480. https://doi. org/10.1007/s10641-004-3154-4

Cohen JH, Forward RB (2005) Diel vertical migration of the marine copepod Calanopia americana. II. Proximate role of exogenous light cues and endogenous rhythms. Marine Biology 147(2): 399-410. https://doi.org/10.1007/s00227-005-1570-4

Costa FO, DeWaard JR, Boutillier J, Ratnasingham S, Dooh RT, Hajibabaei M, Hebert PD (2007) Biological identifications through DNA barcodes: the case of the Crustacea. Canadian Journal of Fisheries and Aquatic Sciences 64(2): 272-295. https://doi.org/10.1139/f07-008

El-Sherbiny MM (2009) First record and redescription of Pontella princeps Dana, 1849 (Copepoda: Pontellidae) in the Red Sea with notes on its feeding habits. Catrina 4(1): 11-20.

El-Sherbiny MM, Al-Aidaroos AM (2017) A new species of Calanopia (Copepoda, Calanoida, Pontellidae) from the plankton of the central Red Sea. Marine Biodiversity 47: 11371145. https://doi.org/10.1007/s12526-017-0694-3

El-Sherbiny MM, Ueda H (2008) Redescription of the poorly known calanoid copepod Pontella karachiensis Fazal-Ur-Rehman, 1973 from the Red Sea with notes on its feeding habits. Plankton and Benthos Research 3(1): 10-17. https://doi.org/10.3800/pbr.3.10

El-Sherbiny MM, Ueda H (2010) Labidocera boxshalli sp. nov., a new calanoid copepod (Crustacea; Pontellidae) from the Red Sea. Organisms Diversity and Evolution 10(1): 23-29. https://doi.org/10.1007/s13127-010-0009-z 
Eyun S, Lee Y, Suh HL, Kim S, Soh HY (2007) Genetic identification and molecular phylogeny of Pseudodiaptomus species (Calanoida, Pseudodiaptomidae) in Korean waters. Zoological Science 24: 265-271. https://doi.org/10.2108/zsj.24.265

Ferrari FD, Ivanenko VN (2008) The identity of protopodal segments and the ramus of maxilla 2 of copepods (Copepoda). Crustaceana 81: 823-835. https://doi. org/10.1163/156854008784771702

Folmer O, Black M, Hoeh W, Lutz R, Vrijenhoek R (1994) DNA primers for amplification of mitochondrial cytochrome c oxidase subunit I from diverse metazoan invertebrates. Molecular Marine Biology and Biotechnology 3: 294-299.

Forward Jr RB (1988) Diel vertical migration: zooplankton photobiology and behavior. Oceanography and Marine Biology: An Annual Review 26: 361-393.

Gurney R (1927) Report on the Crustacea:- Copepoda and Cladocera of the Plankton. The Transactions of the Zoological Society of London 22(2): 139-172. https://doi. org/10.1111/j.1096-3642.1927.tb00328.x

Huys R, Boxshall GA (1991) Copepod Evolution. Ray Society, London, 468 pp.

Jeong HG, Soh HY, Suh HL (2014) Morphological and genetic differentiation of heteromorphy in Labidocera rotunda (Copepoda, Calanoida, Pontellidae). Zootaxa 3764(2): 181191. https://doi.org/10.11646/zootaxa.3764.2.5

Kumar S, Stecher G, Li M, Knyaz C, Tamura K (2018) MEGA X: Molecular evolutionary genetics analysis across computing platforms. Molecular Biology and Evolution 35: 1547-1549. https://doi.org/10.1093/molbev/msy096

Lakkis S (1984) On the presence of some rare copepods in the Levantine Basin. Crustaceana Supplement: 286-304.

Lampert W (1989) The adaptive significance of diel vertical migration of zooplankton. Functional Ecology 3: 21-27. https://doi.org/10.2307/2389671

Mauchline J (1998) The Biology of Calanoid Copepods: Advances in Marine Biology, 33. Academic press, $710 \mathrm{pp}$.

Mulyadi (1997) Three new species of Pontellidae (Copepoda, Calanoida) from coastal waters of Java, Indonesia. Crustaceana 70(6): 653-675. https://doi.org/10.1163/156854097X00113

Ohtsuka S, Soh HY, Ueda H (1998) Platycopia compacta n. sp., the second species of Platycopioida (Crustacea: Copepoda) in the Indo-Pacific region, with remarks on development, feeding, swimming, and zoogeography. Zoological science 15(3): 415-425. https://doi. org/10.2108/zsj.15.415

Pearre Jr S (2003) Eat and run? The hunger/satiation hypothesis in vertical migration: history, evidence and consequences. Biological Reviews 78: 1-79. https://doi.org/10.1017/ S146479310200595X

Pessoa VT, Melo AMC, Júnior M, Neumann-Leitão S (2014) Population dynamics of Calanopia americana Dahl F., 1894 (Copepoda, Calanoida) in a reef environment in tropical Brazil. Tropical Oceanography, Recife 42(1): 24-32. https://doi.org/10.5914/tropocean. v42i1.5783

Pesta O (1941) Die Arten der Copepodengattungen Candacia Dana und Calanopia Dana ausdem Roten Meer. Sitzungsberichte der Akademie der Wissenschaften Wien, (Mathematisch Naturwissenschaftliche Klasse) 150: 157-180. [Figs 1-10] 
Razouls C, De Bovée F, Kouwenberg J, Desreumaux N (2019) Diversity and geographic distribution of marine planktonic copepods. http://copepodes.obs-banyuls.fr/en/ [accessed 8 September 2019]

Sakaguchi SO, Ueda H (2010) A new species of Pseudodiaptomus (Copepoda: Calanoida) from Japan, with notes on the closely related P. inopinus Burckhardt, 1913 from Kyushu Island. Zootaxa 2623(1): 52-68. https://doi.org/10.11646/zootaxa.2623.1.2

Soh HY, Kwon SW, Lee W, Yoon YH (2012) A new Pseudodiaptomus (Copepoda, Calanoida) from Korea supported by molecular data. Zootaxa 3368(1): 229-244. https://doi. org/10.11646/zootaxa.3368.1.11

Soh HY, Moon SY, Park EO, Maran BV (2013) A new species of Acartia subgenus Euacartia (Copepoda: Calanoida: Acartiidae) form Korean estuaries based on morphological and molecular evidence. Journal of Crustacean Biology 33(5): 718-729. https://doi. org/10.1163/1937240X-00002174

Turner JT, Collard SB, Wright JC, Mitchell DV, Steele P (1979) Summer distribution of pontellid copepods in the neuston of the eastern Gulf of Mexico continental shelf. Bulletin of Marine Science 29(3): 287-297.

Ünal E, Shmeleva AA (2002) A new species of Calanopia (Copepoda, Calanoida) from the central Red Sea. Crustaceana 75: 1-11. https://doi.org/10.1163/156854002317373483 